\title{
Requirements for the light-stimulated degradation of stromal proteins in isolated pea (Pisum sativum L.) chloroplasts
}

\author{
Pia Angela Stieger and Urs Feller ${ }^{1}$ \\ Institute of Plant Physiology, University of Bern, Altenbergrain 21, CH-3013 Bern, Switzerland
}

Received 27 November 1996; Accepted 3 May 1997

\begin{abstract}
Chloroplasts from 17-d-old pea leaves (Pisum sativum L.) were isolated to elucidate the requirements for the light-induced degradation of stromal proteins. The influence of electron transport through the thylakoids and the influence of ATP on protein degradation were investigated. When chloroplasts were incubated in the light (45 $\left.\mu \mathrm{mol} \mathrm{m}^{-2} \mathrm{~s}^{-1}\right)$, glutamine synthetase, the large subunit of ribulose-1,5-bisphosphate carboxylase and glutamate synthase were degraded, whereas phosphoribulokinase, ferredoxin-NADP ${ }^{+}$ reductase and the $33 \mathrm{kDa}$ protein of photosystem II remained more stable. Major protein degradation was not observed over $\mathbf{2 4 0} \mathrm{min}$ in darkness. The electron transport inhibitor dichlorophenyldimethylurea reduced protein degradation in the light over several hours, whereas dibromothymoquinone was less effective. Inhibiting the production of ATP with tentoxin or by destroying the $\Delta \mathrm{pH}$ with the ionophores valinomycin and nigericin had no effect or even a stimulating influence on protein degradation when chloroplasts were exposed to light. Furthermore, adding ATP to chloroplasts incubated in the dark had no effect on proteolysis. From these results it is concluded that the transport of electrons through the thylakoids or photooxidative processes associated with it (especially in presence of DTT), rather than the availability of ATP caused the acceleration of stromal protein degradation by light in isolated pea chloroplasts.
\end{abstract}

Key words: Isolated pea chloroplasts, light-induced protein degradation.

\section{Introduction}

Proteolysis is important for the development, function and senescence of plant organelles. Nuclear encoded proteins are proteolytically processed in chloroplasts after uptake across the envelope. In the plastids, newly synthesized immature or incorrectly assembled proteins are removed by proteolysis (Vierstra, 1993; Callis, 1995). Proteins damaged as a consequence of external stresses, such as an excess of light or low temperature, are also removed. For example, the $\mathrm{D} 1$ protein $(32 \mathrm{kDa}$ protein of PSII) is rapidly degraded in light, but not in darkness (Mattoo et al., 1984; Aro et al., 1993). The organelles of pea leaves contain about $80 \%$ of the total nitrogen of a leaf (Makino and Osmond, 1991). Thus, the degradation of proteins in the organelles and the translocation of nitrogen to growing organs is an important process during senescence. Several proteolytic systems in the stroma and associated with thylakoids are known. For example, an ATP-dependent protease has been found by several authors to be responsible for the removal of nonintegrated subunits, newly synthesized proteins containing abnormal amino acids and prematurely terminated proteins (Liu and Jagendorf, 1984, 1985; Malek et al., 1984). In addition an ATP-dependent protease is involved in the degradation of the $25 \mathrm{kDa}$ protein of LHCII when plants are exposed to an excess of light (Lindahl et al., 1995).

ATP-dependent proteolytic systems ( $\mathrm{La}$ and $\mathrm{Clp}$ ) have been described in detail in E. coli (Goldberg, 1992; Maurizi, 1992). The major function of these proteolytic systems is most likely to remove abnormal proteins. The plastids of higher plants contain $\mathrm{ClpP}$ and $\mathrm{ClpC}$, homologues of the ClpP and ClpA of E. coli (Shanklin et al., 1995). Genes encoding the subunit with ATPase activity

\footnotetext{
'To whom correspondence should be addressed. Fax: +413133220 59. E-mall: urs.feller@ptp.unibe.ch
} 
$(\mathrm{ClpC})$ have been identified in the nucleus of several plant species (Gottesmann et al., 1990; Moore and Keegstra, 1993; Ko et al., 1994; Shanklin et al., 1995), whereas the subunit with proteolytic activity (ClpP) is encoded on the chloroplast DNA (Maurizi et al., 1990; Shanklin et al., 1995). Specific functions of the Clp system have not yet been reported for plants. In addition to ATP-dependent systems, a magnesium-stimulated, zinc-dependent protease (EP1) has been found in the stroma of pea chloroplasts and is able to degrade the large subunit (LS) of rubisco (EC 4.1.1.39) (Liu and Jagendorf, 1985, 1986; Bushnell et al., 1993).

In isolated pea chloroplasts exposed to light, a rapid degradation of several stromal proteins has been observed, whereas in the dark these proteins remain stable for several hours (Mitsuhashi and Feller, 1992; Mitsuhashi et al., 1992; Stieger and Feller, 1995). Other workers have shown that the production of activated oxygen species by increased light intensities, elevated oxygen concentrations, or by the addition of the herbicide methyl viologen caused a fragmentation of LS in isolated barley chloroplasts (Desimone et al., 1996). Increased light and oxygen concentrations also accelerated protein degradation in isolated oat chloroplasts (Casano et al., 1990; Casano and Trippi, 1992). Furthermore, oxidative stress initiated by the addition of $\mathrm{CuSO}_{4}$ to Spirodela plants or to isolated wheat chloroplasts led to insolubilization, dimerization and degradation of LS (Mehta et al., 1992). Similar effects were observed when Euglena gracilis was grown in nitrogen-deficient nutrient solution (GarciaFerris and Moreno, 1994).

The degradation of proteins in chloroplasts may be regulated by the abundance and activity of proteases or by the modification of substrate proteins (e.g. oxidation, phosphorylation, acetylation). The observed decrease of stromal proteins in the light might be dependent on ATPconsuming systems. On the other hand, activated oxygen species produced in illuminated chloroplasts might be responsible for an increased susceptibility of stromal proteins to proteolysis. In an attempt to distinguish between the requirement for ATP and effects of activated oxygen species, a series of specific inhibitors was used to block the electron transport or the formation of ATP and the effects on plastid protein breakdown were analysed.

\section{Materials and methods}

Plant matenal and isolation of chloroplasts

Pea plants (Pisum sativum L., cv. Piccolo Petit Provençal) were germinated on wet paper for $4 \mathrm{~d}$ and then grown for $14 \mathrm{~d}$ in hydroponic culture according to Hildbrand et al. (1994), with a photoperiod of $14 \mathrm{~h}\left(120 \mu \mathrm{mol}\right.$ photons $\left.\mathrm{m}^{-2} \mathrm{~s}^{-1}\right)$ at $25 / 21^{\circ} \mathrm{C}$ day/night temperatures. Prior to chloroplast isolation the pea plants were kept for $24 \mathrm{~h}$ in the dark to reduce the starch content in the chloroplasts. Pea leaves were homogenized with a Polytron mixer (Kinematica, Luzern, Switzerland) in grinding buffer ( $50 \mathrm{mM}$ HEPES-NaOH, pH 6.8, $350 \mathrm{mM}$ sorbitol, $2 \mathrm{mM}$ $\mathrm{Na}_{2}$-EDTA, $1 \mathrm{mM} \mathrm{MgCl}, 1 \mathrm{mM} \mathrm{MnCl}_{2}, 5 \mathrm{mM}$ isoascorbic acid, $1 \mathrm{mM}$ dithiothreitol (DTT), $1 \%(\mathrm{w} / \mathrm{v})$ polyethyleneglycol 4000 , and $0.001 \%(w / v)$ spectinomycin), filtrated through two layers of Miracloth (Calbiochem, La Jolla, USA) and centrifuged for $1 \mathrm{~min}$ at $2000 \mathrm{~g}$. The pellet was resuspended in grinding buffer and loaded on 40/80\% (v/v) Percoll steps (Pharmacia, Uppsala, Sweden). To the $40 \%$ Percoll step bovine serum albumin $(0.2 \%, \mathrm{w} / \mathrm{v})$ was added. After centrifugation of the gradients for $12 \mathrm{~min}$ at $1800 \mathrm{~g}$, the chloroplasts were collected from the $80 \%$ Percoll surface and resuspended in grinding buffer. The chloroplasts were then sedimentated by centrifugation for $3 \mathrm{~min}$ at $3000 \mathrm{~g}$ and resuspended in grinding buffer $\left(200 \mu \mathrm{g} \mathrm{chl} \mathrm{ml^{-1 }}\right)$. The purity and intactness of chloroplasts isolated with this procedure were tested as reported previously by Mitsuhashi and Feller (1992). The chloroplast suspensions were incubated in low light $\left(45 \mu \mathrm{mol} \mathrm{m}^{-2} \mathrm{~s}^{-1}\right)$ or in darkness. Where indicated, effectors from stock solutions were added to the incubation medium. The ATP stock solution was neutralized with $\mathrm{NaHCO}_{3}$. Chloroplast suspensions were kept in the dark at $25^{\circ} \mathrm{C}$ for $10 \mathrm{~min}$ to allow the uptake of effectors into the chloroplasts before starting the experiments. After incubation, chloroplasts were reisolated on Percoll steps $(21 / 80 \%)$ as described by Mitsuhashi and Feller (1992) to prevent contamination by lysed chloroplasts.

\section{SDS-PAGE and immunoblotting}

Collected samples were heated for $5 \mathrm{~min}$ with an equal volume of sample buffer (250 mM TRIS- $\mathrm{HCl}$, pH $6.8,4 \%$ SDS, $10 \%$ $\beta$-mercaptoethanol, $20 \%$ glycerol, and $0.03 \%$ bromophenol blue). Gel electrophoresis was carried out according to Laemmli (1970) using $0.75 \mathrm{~mm}$ thick slab gels $(12 \%)$. After electrophoresis, immunoblotting was carried out as described by Mitsuhashi and Feller (1992). Primary antibodies were kindly supplied by $S$ Gepstein (Technion-Israel Institute of Technology, Haifa) against $\mathbf{L S}$ and against the $33 \mathrm{kDa}$ protein of PSII; by G Ochs and A Wild (Johannes-Gutenberg-Universităt, Mainz) against plastidial glutamine synthetase (GS, EC 6.3.1.2); by SJ CraftsBrandner (Western Cotton Research Laboratory, USDA/ARS Phoenix) against phosphoribulokinase (PRK, EC 2.7.1.19); by RM Wallsgrove (IACR-Rothamsted, Harpenden) against ferredoxin-dependent glutamate synthase (GOGAT, EC 1.4.7.1); and by S Ida (Research Institute for Food Science, Kyoto University, Kyoto) against ferredoxin-NADP ${ }^{+}$reductase from rice leaves (FNR, EC 1.18.1.2). All the antibodies used were highly specific (Fig. 1).

\section{Results}

Protein degradation in isolated chloroplasts exposed to light was observed when DTT was present in the grinding buffer and in the incubation medium (Fig, 2A). This result was evident for $\mathbf{L S}$ when proteins were separated and visualized on a Coomassie Brilliant Blue gel and for GS on Western blots. Omitting DTT during chloroplast isolation and incubation stabilized these proteins over $180 \mathrm{~min}$ (Fig. 2A). The substitution of DTT with $\beta$ mercaptoethanol resulted in protein degradation when chloroplasts were exposed to light (Fig. 2B). However, in the dark the proteins remained stable in presence of $\beta$ mercaptoethanol. Thus, it appears likely that DTT can be replaced by other thiols. The following experiments 


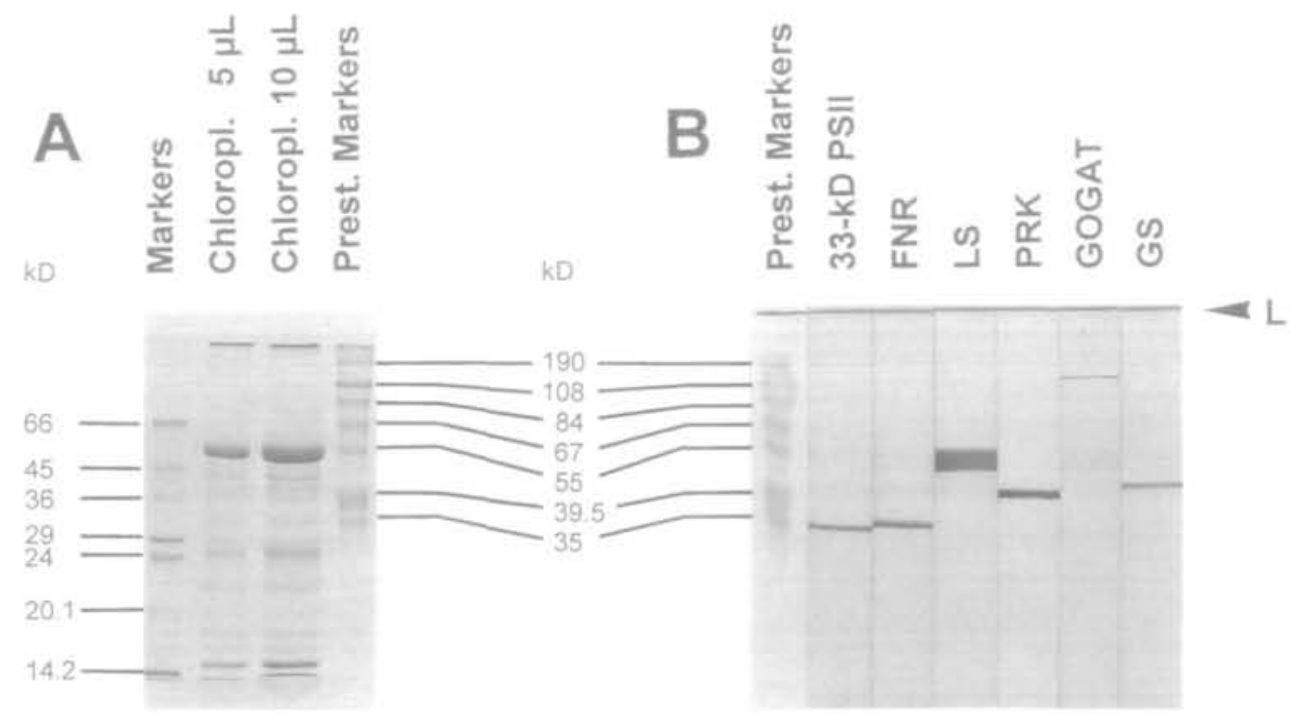

Fig. 1. Specificity of the antıbodies used. The polyacrylamıde gels $(12 \% ; \mathrm{I} \mathrm{mm}$ thick) for staıning (A) and for immunoblots (B) were prepared simultaneously with a sample from freshly isolated chloroplasts (Chloropl.). Samples of 5 and $10 \mu l$ were loaded per lane ( $5 \mathrm{~mm}$ wide) for the stained gel. Markers (SIGMA Dalton Mark VII-L) and prestained markers (SIGMA SDS-7B) were loaded on separate lanes. A special comb with a small ( $3 \mathrm{~mm}$ wide) pocket for the prestained markers and with a large pocket ( $75 \mathrm{~mm}$ wide; loaded with $80 \mu \mathrm{l}$ chloroplast sample) was used for immunoblottıng. A line at the top of the nitrocellulose membrane $(\mathrm{L})$ was drawn before cutting the blot into strips ( $8 \mathrm{~mm}$ wide). The various strips were decorated with the appropriate antibodies and processed according to the standard protocol for immunoblotting. After colour development, the strips were aligned in the original sequence for the photograph.

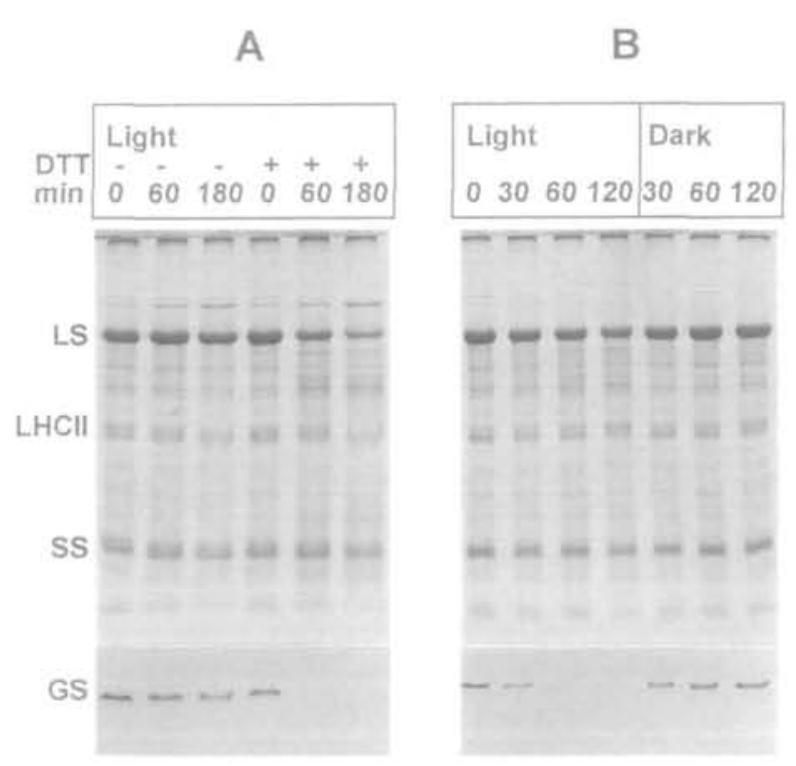

Fig. 2. Influence of thiols on protein degradation in intact chloroplasts. Chloroplast suspensions $\left(200 \mu \mathrm{g} \mathrm{chl} \mathrm{ml}{ }^{-1}\right)$ were exposed to light in the presence $(+)$ or absence $(-)$ of $1 \mathrm{mM}$ DTT $(A)$, or in the presence of $1 \mathrm{mM} \beta$-mercaptoethanol (no DTT) (B). The thiols were added as indicated to the grinding buffer, washing solution and incubation medium. Intact chloroplasts were reisolated from samples taken at the times indicated and equal amounts of chl ( $1 \mu \mathrm{g}$ per lane) were loaded on a $12 \%$ polyacrylamide gel. The large (LS) and small (SS) subunits of Rubisco and LHCII were detected on a stained gel, while GS was visualized by Western blotting.

were all carried out in presence of DTT during chloroplast isolation and incubation.

By adding dichlorophenyldimethylurea (DCMU) to the incubation medium the electron transport chain can be inhibited at the $\mathrm{Q}_{\mathrm{B}}$ site of PSII, whereas dibromothymoquinone (DBMIB) inhibits electron transport at the cyt b/f complex (Nicholls and Ferguson, 1992). These two inhibitors may also affect the production of ATP. Stromal proteins were degraded when chloroplasts were exposed to light (Fig. 3). Most susceptible to degradation in the light were GS, GOGAT and LS, whereas PRK decreased only slightly and FNR was stable. The thy-

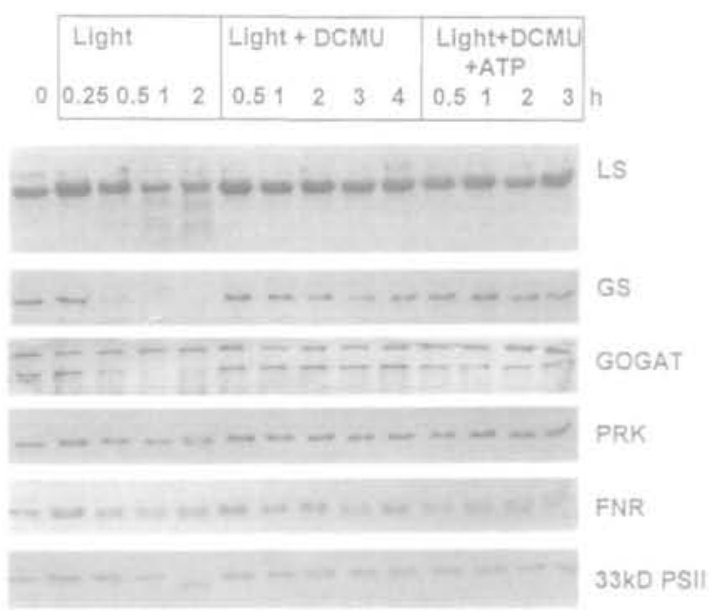

Fig. 3. Influence of DCMU and ATP on protein degradation in intact chloroplasts exposed to light. Chloroplast suspensions $\left(200 \mu \mathrm{g} \mathrm{chl} \mathrm{ml}^{-1}\right)$ were exposed to light and $5 \mu \mathrm{M}$ DCMU or $5 \mathrm{mM}$ ATP (final concentrations) were added to the incubation medium when indicated. Intact chloroplasts were ressolated from all samples and proteins were visualized by Western blotting. Equal amounts of chl ( $1 \mu \mathrm{g}$ per lane for LS, GS, GOGAT, PRK, and the $33 \mathrm{kDa}$ protein of PSII; $2 \mu \mathrm{g}$ per lane for FNR) were loaded on a $12 \%$ polyacrylamide gel. 
lakoid-bound $33 \mathrm{kDa}$ protein of PSII did not show any instability at the light intensities used in this experiment. DCMU in the incubation medium reduced the degradation of stromal proteins drastically. It stabilized the lightsusceptible proteins GS, GOGAT and LS over $4 \mathrm{~h}$ incubation. Adding DBMIB to the incubation medium was not as effective as DCMU (Fig. 4). The light-susceptible proteins GS, GOGAT and LS were only protected over a period of $60 \mathrm{~min}$, afterwards their degradation was as fast as in chloroplasts exposed to light. Incubation of chloroplasts in darkness resulted in protein stability, regardless of the effectors added to the incubation medium (Figs 2, 4).

To differentiate between the influence of ATP and other effects of electron transport through the thylakoids, ATP was added to chloroplasts with DCMU (Fig. 3) or to chloroplasts incubated in the dark (data not shown). No stimulation of proteolysis by ATP was observed under such conditions. Tentoxin, an antagonist of the CF1 subunit of the ATPase, inhibits the production of ATP without directly influencing the electron transport through PSII and PSI (Avni et al., 1992). Similarly, the ionophores nigericin and valinomycin abolish the proton gradient between the stroma and the lumen and, as a consequence, inhibit the production of ATP, but not the electron flow through the thylakoids (Nicholls and Ferguson, 1992). Stromal proteins, especially GS, GOGAT and LS, were degraded when chloroplasts were exposed to light, regardless of the addition of tentoxin to the incubation medium

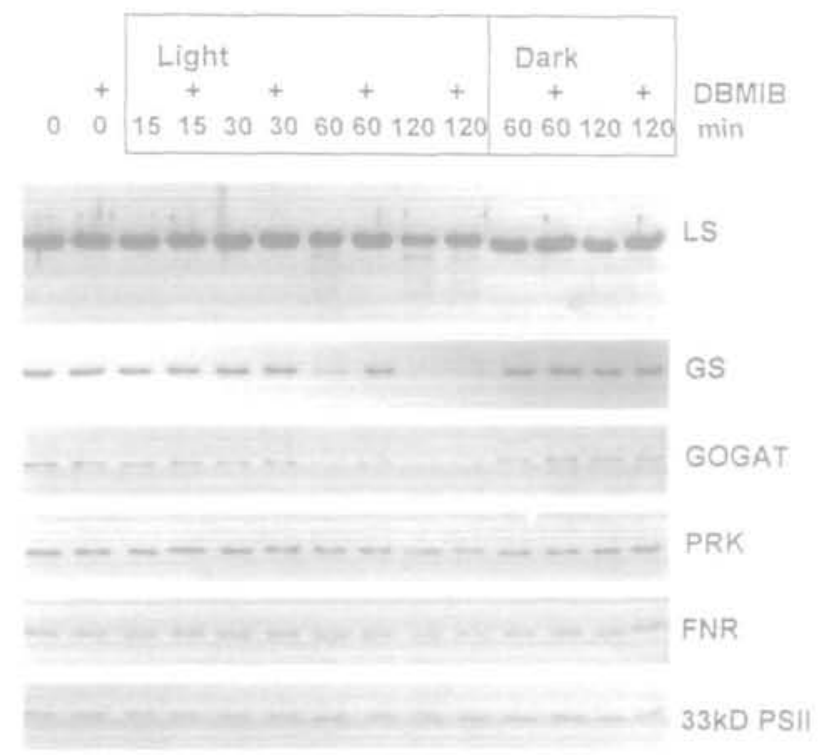

Fig. 4. Influence of DBMIB on protein degradation in intact chloroplasts. Chloroplast suspensions $\left(200 \mu \mathrm{g} \mathrm{chl} \mathrm{ml^{-1 }}\right)$ were exposed to light or darkness and $5 \mu \mathrm{M}$ DBMIB (final concentration) was added to the incubation medium when indicated $(+)$. Intact chloroplasts were reisolated from all samples and proteins were visualized by Western blotting. Equal amounts of chl ( $1 \mu \mathrm{g}$ per lane for LS, GS, GOGAT, PRK, and the $33 \mathrm{kDa}$ protein of PSII; $2 \mu \mathrm{g}$ per lane for FNR) were loaded on a $12 \%$ polyacrylamide gel.
(Fig. 5). In the dark, proteins remained stable in the presence or in the absence of tentoxin. Once again, the proteins PRK, FNR and the $33 \mathrm{kDa}$ protein of PSII were quite stable in chloroplasts exposed to light. The ionophores nigericin and valinomycin had stimulating effects on protein degradation in chloroplasts exposed to light (Fig. 6). Degradation products of LS became visible after $15 \mathrm{~min}$ and the amount of LS decreased faster than in controls without the inhibitor. Similar observations were made for GS, GOGAT and even PRK. The thylakoidbound $33 \mathrm{kDa}$ protein of PSII was stable during the incubation period. In the dark, all proteins remained quite stable and the ionophores had no effect.

\section{Discussion}

The degradation of the stromal proteins GS, GOGAT, and LS in illuminated pea chloroplasts was markedly reduced by the inhibition of electron transport with DCMU. The addition of ATP to such chloroplast suspensions or to chloroplasts incubated in darkness did not accelerate protein degradation. Furthermore, reduction of ATP production in isolated chloroplasts in the light with tentoxin, an antagonist of the CF1-subunit of the ATPase, did not inhibit the degradation of stromal proteins in the light. Destroying the proton gradient between the lumen and the stroma with ionophores even had a stimulating effect on protein degradation in the stroma.

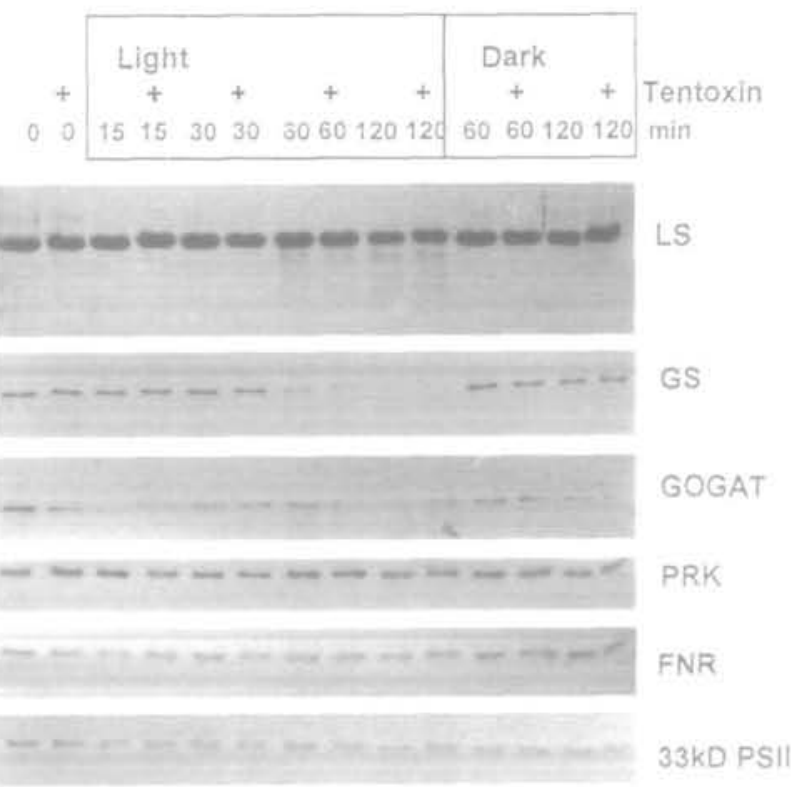

Fig. 5. Influence of tentoxin on protein degradation in intact chloroplasts Chloroplast suspensions $\left(200 \mu \mathrm{g} \mathrm{chl} \mathrm{ml}{ }^{-1}\right)$ were exposed to light or darkness and $5 \mu \mathrm{M}$ tentoxin (final concentration) was added to the incubation medium when indicated $(+)$. Intact chloroplasts were ressolated from all samples and proteins were visualized by Western blotung. Equal amounts of chl ( $1 \mu \mathrm{g}$ per lane for LS, GS, GOGAT, $\mathrm{PRK}$, and the $33 \mathrm{kDa}$ protein of PSII; $2 \mu \mathrm{g}$ per lane for FNR) were loaded on a $12 \%$ polyacrylamide gel. 


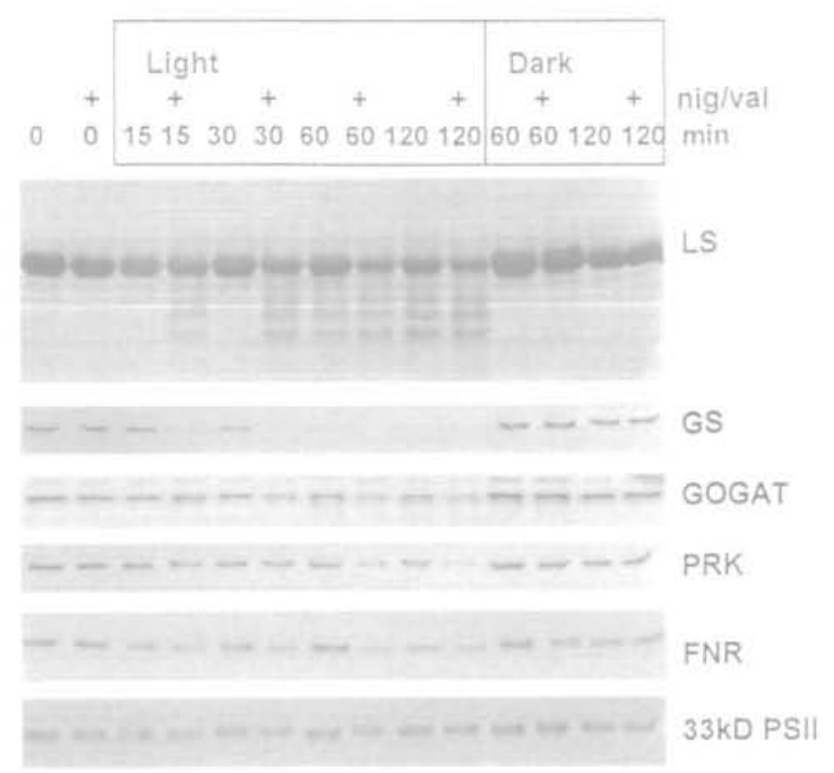

Fig. 6. Influence of the ionophores nigericin and valinomycin on protein degradation in intact chloroplasts. Chloroplast suspensions $(200 \mu \mathrm{g}$

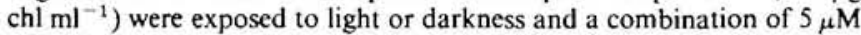
nigericin, $5 \mu \mathrm{M}$ valinomycin and $1 \mathrm{mM} \mathrm{KCl}$ (final concentrations) was added to the incubation medium when indicated $(+)$. Intact chloroplasts were reisolated from all samples and protenns were visualized by Western blotting. Equal amounts of chl ( $1 \mu \mathrm{g}$ per lane for LS, GS, GOGAT, PRK, and the $33 \mathrm{kDa}$ protein of PSII; $2 \mu \mathrm{g}$ per lane for FNR) were loaded on a $12 \%$ polyacrylamide gel.

From these results, it was concluded that the availability of ATP is not crucial for the initial steps of GS, GOGAT and LS degradation.

Comparing the effects of the two electron transport inhibitors DCMU and DBMIB, it was noticed that DCMU was much more effective than DBMIB. DCMU binds to the $\mathrm{Q}_{\mathrm{B}}$-binding site of PSII, whereas DBMIB interacts with the cytochrome $b / f$ complex. Elstner and Frommeyer (1978) measured no production of $\mathrm{O}_{2}^{-}$and $\mathrm{H}_{2} \mathrm{O}_{2}$ when DCMU was added to isolated thylakoids, whereas the addition of DBMIB resulted in the formation of $\mathrm{H}_{2} \mathrm{O}_{2}$. In the latter case, electrons are transferred from $\mathrm{Q}_{\mathrm{A}}$ to $\mathrm{Q}_{\mathrm{B}}$ forming the protonated plastoquinol from which electrons may be transferred to $\mathrm{O}_{2}$ (Kyle, 1987).

The ATPase inhibitor tentoxin binds to the $\beta$-subunit of CF1 (Avni et al., 1992) and has no major effects on the electron transport chain in the thylakoids (Bulychev and Dahse, 1984; Dahse et al., 1986). Therefore, the amount of activated oxygen species produced would be very similar in tentoxin-treated and untreated chloroplasts exposed to light. In contrast, the ionophores nigericin and valinomycin in the presence of $\mathrm{K}^{+}$ions destroy the proton gradient and the $\Delta \mathrm{pH}$ across the thylakoids, without reducing the flow of electrons through the membrane. The $\Delta \mathrm{pH}$ is an important regulatory component in the dissipation of excess energy via the xanthophyll cycle, the xanthophyll cycle-dependent energy quenching being inhibited at a low $\Delta \mathrm{pH}$ (Gilmore et al., 1995).
Furthermore, DTT and $\beta$-mercaptoethanol strongly inhibit violaxanthin de-epoxidase and ascorbate peroxidase, two central enzymes of the radical detoxifying mechanisms known in chloroplasts (Yamamoto and Kamite, 1972; Chen and Asada, 1992; Neubauer, 1993). DTT in the presence of $\mathrm{Fe}^{3+}$ and $\mathrm{O}_{2}$ might give rise to thiyl or oxygenated sulphur radicals (Netto and Stadtman, 1996). The effects of DTT causing an accumulation of radicals by increasing their formation or by inhibiting their detoxification could explain the improved stability of stromal enzymes in these experiments when chloroplasts were incubated in the light in the absence of DTT.

In previous work (Mitsuhashi et al., 1992), LS fragments with molecular weights of $45,42,37$, and $32 \mathrm{kDa}$ were described. Recently, similar fragments were also detected when barley chloroplasts were exposed to high doses of oxygen and light or to the herbicide methyl viologen (Desimone et al., 1996). These fragments are in the range between 48 and $36 \mathrm{kDa}$, the $36 \mathrm{kDa}$ being the most abundant. Such polypeptides may accumulate under conditions which favour the production of free radicals. In E. coli, GS is known to be very sucseptible to radical attack. The protein is first oxidized to a catalytically inactive form and then this form is quickly degraded by intracellular proteases (Levine et al., 1981). In this experimental system, GS was the most labile of the stromal proteins investigated, its degradation being very fast in the light. Nevertheless, it remained stable over several hours when DTT was removed from the incubation medium, when DCMU was added or when chloroplasts were incubated in darkness. On the other hand, PRK, FNR and the $33 \mathrm{kDa}$ protein of PSII were quite stable in chloroplasts exposed to light. The $33 \mathrm{kDa}$ protein is peripherally bound to the oxygen-evolving system on the lumenal side of the thylakoid membrane and functions as the Mn-stabilizing protein (Yamamoto, 1988). In addition, it stabilizes the CP43 protein under photoinhibitory conditions (Yamamoto and Akasaka, 1995). In bean leaves it remains stable until late in senescence (Roberts et al., 1987). Thus, it was not surprising that no decrease of the $33 \mathrm{kDa}$ protein was observed in this work. Proteins with a metal-binding site can be oxidized in a site-specific manner by reaction of $\mathrm{Fe}$ (II) with $\mathrm{H}_{2} \mathrm{O}_{2}$ forming hydroxyl radicals (Stadtman, 1992). In plants, Rubisco and GS possess a cation binding site near the catalytic centre which normally binds $\mathrm{Mg}^{2+}$ but which can also bind $\mathrm{Fe}^{2+}$.

In this work the light-stimulated degradation of stromal proteins occurred only when the electron transport chain was functioning. The inhibition of ATP production did not influence this degradation process. From these results, it was concluded that the modification of stromal proteins by activated oxygen species rather than the stimulation of an ATP-dependent protease is the first step leading to the degradation of stromal enzymes. The three- 
dimensional structure of the proteins may be relevant for their susceptibility to radical attack. The characterization and purification of proteases digesting such modified proteins will be a task for future work.

\section{Acknowledgements}

We thank Regına Hölzer for technical assıstance, Dr Samuel Roulin for helpful discussions, and Dr Andrew Fleming for improving the English of the manuscript. This work was supported by the Swiss National Science Foundation (Project 3100-043174.95).

\section{References}

Aro E-M, Virgin I, Andersson B. 1993. Photoinhibition of photosystem II. Inactivation, protein damage and turnover. Biochimica et Biophysica Acta 1143, 113-34.

Avni A, Anderson JD, Holland N, Rochaix J-D, Gromet-Elhanan Z, Edelman M. 1992. Tentoxin sensitivity of chloroplasts determined by codon 83 of $\beta$ subunit of proton-ATPase. Science 257, 1245-7.

Bulychev AA, Dahse I. 1984. Light-induced electric potentials of intact Anthoceros chloroplasts and their modification in the presence of the energy transfer inhibitor tentoxin. Biochemie und Physiologie der Pflanzen 179, 685-92.

Bushnell TP, Bushnell D, Jagendorf AT. 1993. A purified zinc protease of pea chloroplasts, EP1, degrades the large subunit of ribulose-1,5-bisphosphate carboxylase/oxygenase. Plant Physiology 103, 585-91.

Callis J. 1995. Regulation of protein degradation. The Plant Cell 7, 845-57.

Casano LM, Gomez LD, Trippi VS. 1990. Oxygen- and lightinduced proteolysis in isolated oat chloroplasts. Plant and Cell Physiology 31, 377-82.

Casano LM, Trippi VS. 1992. The effect of oxygen radicals on proteolysis in isolated oat chloroplasts. Plant and Cell Physiology 33, 329-32.

Chen G-X, Asada K. 1992. Inactivation of ascorbate peroxidase by thiols requires hydrogen peroxide. Plant and Cell Physiology 33, 117-23.

Dahse I, Matorin DN, Liebermann B. 1986. A comparision of tentoxin action on the delayed fluorescence in chloroplasts of spinach, Chlorella and Anacystis. Biochemie und Physiologie der Pflanzen 181, 137-46.

Desimone M, Henke A, Wagner E. 1996. Oxidative stress induces partial degradation of the large subunit of ribulose-1,5-bisphosphate carboxylase/oxygenase in isolated chloroplasts of barley. Plant Physiology 111, 789-96.

Elstner EF, Frommeyer D. 1978. Production of hydrogen peroxide by photosystem II of spinach chloroplast lamellae. FEBS Letters 86, 143-6.

Garcia-Ferris C, Moreno J. 1994. Oxidative modification and breakdown of ribulose-1,5-bisphosphate carboxylase/ oxygenase inuced in Euglena gracilis. Planta 193, 208-15.

Gilmore AM, Hazlett T, Govindjee. 1995. Xanthophyll cycledependent quenching of photosystem II chlorophyll $a$ fluorescence: formation of a quenching complex with a short fluorescence lifetime. Proceedings of the National Academy of Science, USA 92, 2273-7.

Goldberg AL. 1992. The mechanism and functions of ATPdependent proteases in bacterial and animal cells. European Journal of Biochemistry 203, 9-23.
Gottesman S, Squires C, Pichersky E, Carrington M, Hobbs M, Mattick JS, Dalrymple B, Kuramitsu H, Shiroza T, Foster T, Clark W, Ross B, Squires CL, Maurizi MR. 1990. Conservation of the regulatory subunit for the Clp ATPdependent protease in prokaryotes and eukaryotes. Proceedings of the National Academy of Science, USA 87, 3513-7.

Hildbrand M, Fischer A, Feller U. 1994. Protein catabolism in bean leaf discs: accumulation of a soluble fragment of ribulose-1,5-bisphosphate carboxylase/oxygenase under oxygen deficiency. Journal of Experimental Botany 45, $1197-1204$.

Ko K, Doung C, Ko ZW. 1994. Nucleotide sequence of a Brassica napus Clp homolog. Plant Physiology 104, 1087-9.

Kyle DJ. 1987. The biochemical basis for photoinhibition of photosystem II. In: Kyle DJ, Osmond CB, Arntzen CJ, eds. Photoinhibition. Amsterdam: Elsevier, 197-227.

Laemmli UK. 1970. Cleavage of structural proteins during the assembly of the head of bacteriophage T4. Nature 227, 680-5.

Levine RL, Oliver CN, Fulks RM, Stadtman ER. 1981. Turnover of bacterial glutamine synthetase: oxidative inactivation precedes proteolysis. Proceedings of the National Academy of Science, USA 78, 2120-4.

Lindahl M, Yang D-H, Andersson B. 1995. Regulatory proteolysis of the major light-harvesting chlorophyll $a / b$ protein of photosystem II by a light-induced membrane-associated enzymic system. European Journal of Biochemistry 231, 503-9.

Liu X-Q, Jagendorf AT. 1984. ATP-dependent proteolysis in pea chloroplasts. FEBS Letters 166, 248-52.

Liu X-Q, Jagendorf AT. 1985. Roles for ATP-dependent and ATP-independent proteases of pea chloroplasts in regulation of the plastid translation products. Physiologie Végétale 23, 749-55.

Liu X-Q, Jagendorf AT. 1986. Neutral peptidases in the stroma of pea chloroplasts. Plant Physiology 81, 603-8.

Makino A, Osmond B. 1991. Effects of nitrogen nutrition on nitrogen partitioning between chloroplasts and mitochondria in pea and wheat. Plant Physiology 96, 355-62.

Malek L, Bogorad L, Ayers AR, Goldberg AL. 1984. Newly synthesised proteins are degraded by an ATP-stimulated proteolytic process in isolated pea chloroplasts. FEBS Letters 166, 253-7.

Mattoo AK, Hoffman-Falk H, Marder JB, Edelman M. 1984. Regulation of protein metabolism: coupling of photosynthetic electron transport to in vivo degradation of the rapidly metabolized 32-kilodalton protein of the chloroplast membranes. Proceedings of the National Academy of Science, USA 81, $1380-4$.

Maurizi MR. 1992. Proteases and protein degradation in Escherichia coli. Experientia 48, 178-201.

Maurizi MR, Clark WP, Kim S-H, Gottesman S. 1990. Clp P represents a unique family of serine proteases. Journal of Biological Chemistry 265, 12546-52.

Mehta RA, Fawcett TW, Porath D, Mattoo AK. 1992. Oxidative stress causes rapid membrane translocation and in vivo degradation of ribulose-1,5-bisphosphate carboxylase/ oxygenase. Journal of Biological Chemistry 267, 2810-16.

Mitsuhashi W, Crafts-Brandner S.J, Feller U. 1992. Ribulose-1,5-bisphosphate carboxylase/oxygenase degradation in isolated pea chloroplasts incubated in the light or in the dark. Journal of Plant Physiology 139, 653-8.

Mitsuhashi W, Feller U. 1992. Effects of light and external solutes on the catabolism of nuclear-encoded stromal proteins in intact chloroplasts isolated from pea leaves. Plant Physiology 100, 2100-5.

Moore T, Keegstra K. 1993. Characterization of a cDNA clone 
encoding a chloroplast-targeted Clp homologue. Plant Molecular Biology 21, 525-37.

Netto LES, Stadtman ER. 1996. The iron-catalyzed oxidation of dithiothreitol is a biphasic process: hydrogen peroxide is involved in the initiation of a free radical chain of reactions. Archives of Biochemistry and Biophysics 333, 233-42.

Neubauer C. 1993. Multiple effects of dithiothreitol on nonphotochemical fluorescence quenching in intact chloroplasts. Plant Physiology 103, 575-83.

Nicholls DG, Ferguson SJ. 1992. In: Bioenergetics 2. London: Academic Press, 23-37, 157-87.

Roberts DR, Thompson JE, Dumbroff EB, Gepstein S, Mattoo AK. 1987. Differential changes in the synthesis and steadystate levels of thylakoid proteins during bean leaf senescence. Plant Molecular Biology 9, 343-53.

Shanklin J, DeWitt ND, Flanagan JM. 1995. The stroma of higher plant plastids contain $\mathrm{ClpP}$ and $\mathrm{ClpC}$, functional homologs of Escherichia coli $\mathrm{ClpP}$ and ClpA: an archetypal two-component ATP-dependent protease. The Plant Cell 7, 1713-22.
Stadtman ER. 1992. Protein oxidation and aging. Science 257, 1220-4.

Stieger PA, Feller U. 1995. Influence of external factors on the catabolism of stromal proteins in isolated pea chloroplasts. In: Mathis $\mathrm{P}$, ed. Photosynthesis: from light to biosphere. Dordrecht: Kluwer Academic Publishes, 223-6.

Vierstra RD. 1993. Protein degradation in plants. Annual Review of Plant Physiology and Plant Molecular Biology 44, 385-410.

Yamamoto Y. 1988. Organization of the oxygen-evolution enzyme complex studied by butanol/water phase partitioning of spinach photosystem II. Journal of Biological Chemistry 263, 497-500.

Yamamoto Y, Akasaka T. 1995. Degradation of antenna chlorophyll-binding protein CP43 during photoinhibition of photosystem II. Biochemistry 34, 9038-45.

Yamamoto H, Kamite L. 1972. The effects of dithiothreitol on violaxanthin de-epoxidation and absorbance changes in the $500 \mathrm{~nm}$ region. Biochimica et Biophysica Acta 267, 538-43. 